\title{
The Influence of Brand Image, Product Innovation and Social Media Marketing on Samsung Smartphone's Buying Interest: Case Study on Narotama University Students
}

\author{
Prama Wildan Ardiansyah ${ }^{1}$, Sengguruh Nilowardono ${ }^{2}$ \\ Narotama University Surabaya \\ wldanardiansyah@gmail.com
}

\begin{abstract}
The purpose of this study is to examine the influence of Brand Image, Product Innovation and Social Media Marketing on Samsung Smartphone Buying Interest. The independent variables of this study are brand image, product innovation and social media marketing, while the dependent variable is buying interest. This is a quantitative research. The sample counted 100 respondents the data is collected through surveys from questioner tool. The data were analyzed using multiple linear regression and using the SPSS version 16.00. The results showed that Brand Image (X1), Product Innovation (X2) and Social Media Marketing (X3) have a positive and significant influence simultaneously on Samsung smartphone buying interest (Y). Brand Image variable (X1) does not have a significant influence partially on buying interest (Y). The adjusted $\mathrm{R}$ square value is 0.609 which means that the influence of independent variables on the dependent variable is $60.9 \%$.
\end{abstract}

Keywords : Brand Image, Product Innovation, Social Media Marketing, Buying Interest.

\section{INTRODUCTION}

\section{Research Background and Motives}

Current technological developments are very rapid. Every company must be able to keep up with the rapid development of technology so that they do not lose in competition. There are already many sophisticated products created due to technological advancements. This technological development has a huge influence on the development of smartphones in the world. Until now, many sophisticated smartphones have been created by utilizing existing technology.

Indonesia is a country with a very large number of smartphone users. In fact, Indonesia is one of the four largest smartphone user countries. So Indonesia is a "money field" for smartphone manufacturers. Currently, many smartphone companies market their products in Indonesia. One of these companies is Samsung. Samsung is the largest company in South Korea. Samsung is a manufacturer of electronic devices. Samsung continues to make excellent innovations and promotions. And now Samsung is the king of all smartphone manufacturers. Evident from the number of new smartphones launched each year. In every shopping center we often find Samsung's billboards.

The Influence of Brand Image, Product Innovation and Social Media Marketing on Samsung 


\section{Indonesia Top 5 Smartphone Companies by Year over Year (YOY) Market Share Comparation, 2Q18}

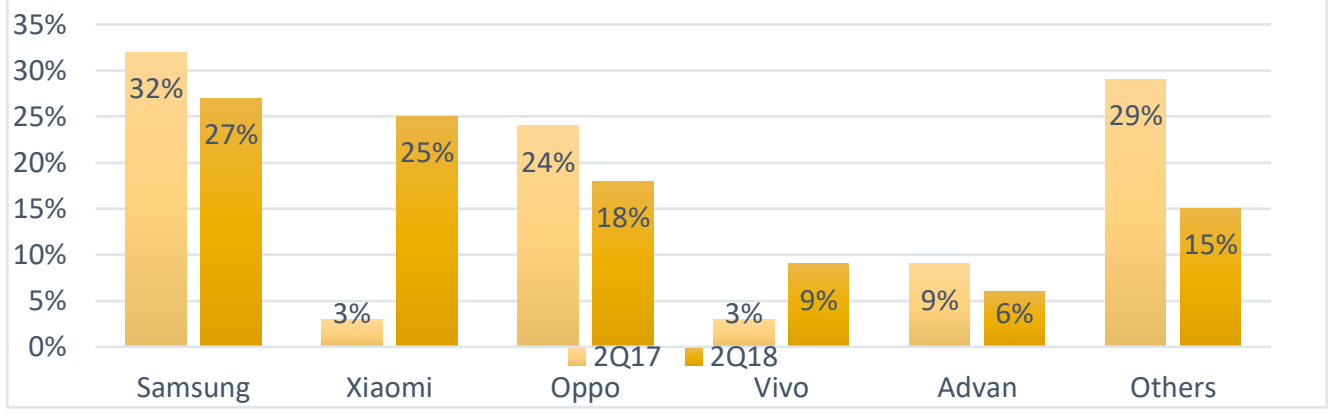

Fig. 1. Data 5 teratas perusahaan smartphone pada kuartal 2 tahun 2018

Source : IDC 2018

Based on the data above, Samsung still leads with a market share of $27 \%$. This figure fell $5 \%$ compared to the same period last year. Samsung's position is very threatened by Xiaomi's smartphone brand with a market share of $25 \%$. This figure is up $22 \%$ compared to the same period this year. That means only $2 \%$ adrift to capture Samsung's current position. The third position is the Oppo smartphone brand with a market share of $18 \%$. This figure is down $8 \%$ compared to the same period this year. The two Chinese smartphone companies have very good levels of product innovation and promotional activities. It's just that their brand image is not as good as Samsung, which has made many achievements in the electronic device industry.

Due to the large number of competitors, Samsung has decreased its smartphone sales this quarter, but Samsung is still the king of the smartphone market today. So Samsung must have a good strategy in marketing its products. One of the marketing strategies is the promotion. Promotion is an activity to provide information and offer products to prospective consumers to buy and consume our products. Promotion can be applied through online media such as social media. Nowadays there are a lot of social media used by the community. Facebook, Twitter, Instagram, Youtube and many others. Social media marketing is a way to promote products or services online. Social media marketing is also very helpful for promotional activities because it is easier to implement and requires smaller promotional costs. Large companies should use social media marketing as one of their promotional activities.

In addition to promotion, product innovation is also very important in attracting consumer buying interest. With a more innovative smartphone, it will attract consumers to buy the smartphone. Each brand has a different product innovation. There are manufacturers who focus on the sophistication of their smartphone cameras. There are also manufacturers who focus on screen quality and smartphone screen size. With the creation of these innovative products, it will help companies achieve company goals.

One more important thing in a company is brand image. Brand image is a consumer's perception of a brand as a reflection of the association that exists in the consumer's mind. Brand image is an association that arises in the minds of consumers when remembering a particular brand. Such associations can simply appear in the form of certain thoughts and images associated with a brand (Kotler \& Keller, 2016).

\footnotetext{
The Influence of Brand Image, Product Innovation and Social Media Marketing on Samsung

Smartphone's Buying Interest: Case Study on Narotama University Students

Prama Wildan Ardiansyah, Sengguruh Nilowardono
} 
Companies around the world definitely want a good brand image. With a good brand image, consumers will be more confident in a company.

1) Based on the things mentioned above, the problems to be examined are:

2) Does brand image has a partially significant influence on Samsung smartphone buying interest?

3) Does product innovation has a partially significant influence on Samsung smartphone buying interest?

4) Does social media marketing has a partially significant influence on Samsung smartphone buying interest?

5) Do brand image, product innovation and social media marketing have a simultaneously significant influence on Samsung smartphone buying interest

The objectives of this study are:

1) To analyze the influence and significance of brand image on Samsung smartphone buying interest?

2) To analyze the influence and significance of product innovation on Samsung smartphones buying interest?

3) To analyze the influence and significance of social media marketing on Samsung smartphone buying interest?

4) To analyze the influence and significance of brand image, product innovation and social media marketing on Samsung smartphone buying interest?

\section{LITERATURE REVIEW}

\section{Brand Image}

Brand is not just a company logo or name, but an image or perception of someone about a product or company. A brand is a complete combination of associations that people imagine when they hear a company or product name. A brand is anything related to a company, product, or service of all attributes, both tangible and intangible (Ningrum \& Nilowardono, 2016). Brand image presents the overall perception of consumers towards the brand formed because of information and experience of consumers on a brand. The image of the brand has an important role in influencing purchasing behavior. Consumers who have a positive image of the brand tend to choose the brand in the purchase. Positive brand image can be built with uniqueness, the superiority that stands out from the brand itself and has differences with other products (Suryani, 2013). Based on these understandings it can be concluded that brand image is a person's perception or belief in a brand, and brand image can influence buying behavior.

\section{Product Innovation}

Product innovation is the result of developing new products by a company or industry, both those that already exist and have not. From old products that have reached saturation in the market, an innovation is needed to replace the old product. This replacement can be done with replacement products that are totally new or with the development of old products that are more modern and up to date, so they can continue to increase the desire of consumers to buy these products.

\section{Social Media Marketing}

Social Media Marketing is a type of internet marketing model to achieve marketing goals by participating in various social media networks. Social media marketing tools generally include BBS, micro blogging, blogs, SNS, images, videos, etc. (Mao, Zhu, \& Sang, 2014). Social network marketing is used by strategic marketers as a marketing tool because these social networks are hugely popular among individuals and thus become visible sites for advertising (Toor, Husnain, \& Hussain, 2017). Social media marketing is an

\footnotetext{
The Influence of Brand Image, Product Innovation and Social Media Marketing on Samsung

Smartphone's Buying Interest: Case Study on Narotama University Students

Prama Wildan Ardiansyah, Sengguruh Nilowardono
} 
internet-based marketing model using social media as an intermediary. Many producers actively use social media for advertising and marketing because it is very helpful in the context of communication with customers.

\section{Buying Interest}

According to Hasan in (Ghristian, 2016) purchase intention is the tendency of consumers to buy a brand or take actions related to purchases that are measured by the level of possibility that consumers make a purchase. When a consumer attracts a specific brand it is known as purchase intention (Mehmood \& Shafiq, 2015). Based on the above understanding it can be concluded that buying interest is the consumer's interest in a particular brand by considering certain rating scales.

\section{RESEARCH METHOD}

\section{Research Structure}

Based on the aims and relevant literature, this study proposes a research model of the effects of brand image, poduct innovation, and social media marketing on buying interest, and the model is showed in Figure 2:

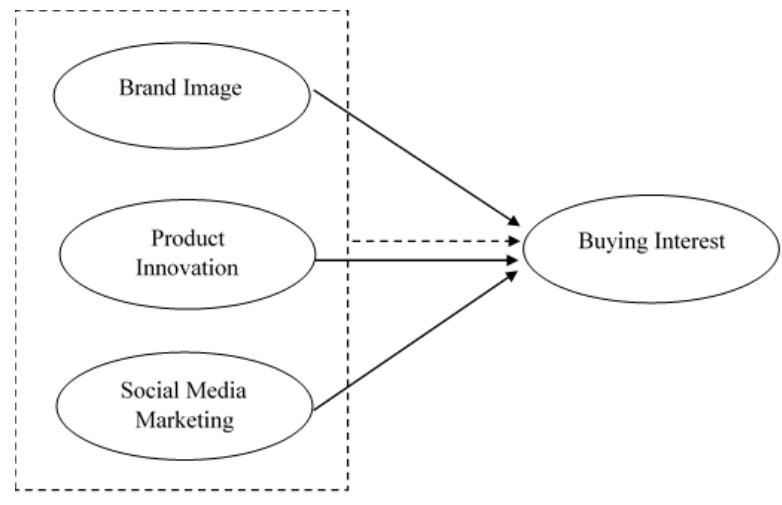

Fig. 2. Research Framework

\section{Research Hypotheses}

H1 : Brand image partially has a significant influence on Samsung smartphone buying interest?

H2 : Product Innovation partially has a significant influence on Samsung smartphone buying interest?

H3 : Social Media Marketing partially has a significant influence on Samsung smartphone buying interest?

H4 : Brand image, product innovation and social media marketing simultaneously have a significant influence on Samsung smartphone buying interest? 


\section{Technique}

We have used Quantitative technique in this research, which is focused on the collection of numerical data for statistical analysis.

\section{Population}

We have collected the data from students of Narotama University. Data collection was based on questionnaire.

\section{Sampling Technique}

This research uses non probability sampling with incidental sampling approach.

\section{RESULTS AND DISCUSSION}

\section{Validity Test and Reliability Test}

The test results show that all items in question regarding brand image, product innovation, social media marketing and product purchase interest are 19 items declared valid because they have value of $r>$ rtable values. While the results of the reliability test show Cronbach alpha value of 0.978 and greater than 0.6 . So this research data can be declared reliable.

\section{Multiple Regression Analysis}

Multiple linear regression analysis is used to explain how the influence of independent variables, namely Brand Image (X1), Product Innovation (X2) and Social Media Marketing (X3) on the dependent variable, namely Buying Interest $(\mathrm{Y})$. In calculating multiple linear regression analysis, researchers used the SPSS 16.0 application. Summary of data processing can be seen in the following table:

Table. 1. Model Summary

\begin{tabular}{lccc}
\hline \multicolumn{1}{c}{ Variable } & $\begin{array}{c}\text { regression } \\
\text { coefficient }\end{array}$ & t & sig \\
\hline Brand Image (X1) & 0,059 & 0,469 & 0,640 \\
Product Innovation(X2) & 0,485 & 3,647 & 0,000 \\
Social Media Marketing (X3) & 0,322 & 2,600 & 0,011 \\
\hline
\end{tabular}

Konstanta $=0,530$

$\mathrm{R}=0,788$

Adj R Square $=0,609$

$\mathrm{F}=52,344$

Fsig $=0,000$

$\mathrm{N}=100$

$\mathrm{SEE}=0,387$ 

are:

Regression equation models that can be written based on the multiple regression analysis table above

Y

$$
=0,53+0,059 \mathrm{X} 1+0,485 \mathrm{X} 2+0,322 \mathrm{X} 3+\mathrm{e}
$$

$Y \max$

$$
=1,297+0,059 \mathrm{X} 1+0,485 \mathrm{X} 2+0,322 \mathrm{X} 3
$$

Ymin

$$
=0,059 \mathrm{X} 1+0,485 \mathrm{X} 2+0,322 \mathrm{X} 3-0,237
$$

Based on the equation model above, the constant value is 0.53 , this indicates that the value of buying interest (Y) is 0.53 units if it is assumed that brand image (X1), product innovation (X2) and social media marketing (X3) is 0 . If the value of the independent variable 0 , the value of dependent variable is 0.53 .

Brand image regression coefficient (X1) is 0.059. It means that if Samsung increases the influence of brand image and other variables of product innovation (X2) and social media marketing (X3) are fixed, it will increase buying interest (Y) by 0.059 units. Product innovation regression coefficient (X2) is 0.485 . This means that if Samsung increases the influence of product innovation and other variables of brand image (X1) and social media marketing (X3) are fixed, it will increase buying interest (Y) by 0.485 units. The social media marketing regression coefficient $(\mathrm{X} 3)$ is 0.322 . This means that if Samsung increases the influence of social media marketing and other variables of brand image (X1) and product innovation (X2) are fixed, it will increase buying interest (Y) by 0.322 units.

Based on the above table data it is known that the calculated $\mathrm{F}$ value obtained is 52,344 . This value is greater than $\mathrm{F}$ table 2,699. Also obtained a significance value of $0,000<0,05$. So Ha is accepted, meaning that the brand image (X1), product innovation (X2) and social media marketing (X3) simultaneously have a significant influence on buying interest (Y) of Samsung smartphones.

Based on the data table above it is known that the T value of variable brand image (X1) is $0.469<$ 1.984. Also obtained a significance value of $0.640>0.05$. This shows that the brand image variable (X1) has no partial influence on the purchase interest variable (Y). The $\mathrm{T}$ value of product innovation variable $(\mathrm{X} 2)$ is $3.647>1.984$. Also obtained a significance value of $0,000<0,05$. This shows that the product innovation variable (X2) has a partially significant influence on buying interest variables (Y). The T value of social media marketing variable $(\mathrm{X} 3)$ is $2,600>1,984$. Also obtained a significance value of $0.011<$ 0.05 . This shows that the social media marketing variable (X3) has a partially significant influence on the buying interest variable (Y).

Based on the data, the $\mathrm{R}$ value is 0.788 . It means that correlation or relationship between buying interest with 3 independent variables (brand image, product innovation and social media marketing) have a strong relationship because the value of $\mathrm{R}$ is $0.788>0.5$.

Obtained the coefficient of determination or Adjusted $\mathrm{R}$ square is 0.609 which means that the dependent variable of buying interest (Y) can be explained by the independent variable brand image (X1), product innovation (X2) and social media marketing (X3) of 0.609 or $60.9 \%$ and the rest $(100 \%-60.9 \%$ $=39.9 \%$ ) is explained by other variables not included in the model.

Obtained the SEE value (Standard Error of Estimate) is 0.387 . This means that the regression model error rate is $38.7 \%$. The smaller the SEE value, the regression model is better at predicting buying interest.

\section{Normality Test}

Based on the P-Plot output, it can be seen that the points spread around the diagonal line and follow the direction of the diagonal line. Then it can be concluded that the regression model is normally distributed.

\footnotetext{
The Influence of Brand Image, Product Innovation and Social Media Marketing on Samsung

Smartphone's Buying Interest: Case Study on Narotama University Students

Prama Wildan Ardiansyah, Sengguruh Nilowardono
} 


\section{Multicollinearity Test}

The results of the multicollinearity test show that all independent variables have tolerance values above 0.10 and VIF values below 10. Then it can be concluded that there is no multicollinearity in the regression model used in this study.

\section{Heteroscedasticity Test}

The scatterplot output test results show that the points spread above and below 0 on the $\mathrm{Y}$ axis and do not form a clear pattern. So that it can be concluded that there is no heteroscedasticity in the regression model.

\section{CONCLUSION AND SUGGESTIONS}

\section{Conclusion}

Based on the results and discussion in chapter IV it can be concluded as:

1) Based on data processing using SPSS V.16.0. Obtained a calculated F value is 52,344 . This value is more than $\mathrm{F}$ table 2,699. Also obtained a significance value is $0,000<0,05$. This means that Ho is rejected and $\mathrm{Ha}$ is accepted, the brand image variable (X1), product innovation (X2), and social media marketing (X3) have a simultaneous significant effect on buying interest variables (Y). This shows that each of the research variables is taken into consideration for prospective Samsung smartphone customers.

2) Partially the three variables have their respective results, for the brand image variable the influence is not partially significant on consumer buying interest in Samsung smartphones. This shows that the brand image is not too a consideration for prospective customers. Product innovation variables have a partially significant influence on consumer buying interest in Samsung smartphones. This shows that Samsung's product innovation is in line with the expectations of prospective customers. Social media marketing variables have a partially significant influence on consumer buying interest in Samsung smartphones. This indicates that Samsung's social media marketing is in line with the expectations of prospective customers.

\section{Suggestions}

1) For Further Researchers

The suggestion for the next researcher is to identify other variables that influence consumer buying intentions, because the variables used in this study are only able to influence consumer buying interest by $60.9 \%$.

\section{2) For Companies}

Researchers suggest that Samsung pay attention to the three research variables used by researchers. Continue to improve the brand image even though the inluence is not significant, but the brand image still has a stake in the basis of decision making for consumers. Samsung must also continue to improve its ability to innovate. In this study, product innovation has the highest significance value. So product innovation must be continuously improved so that it can influence consumers' buying interest very well. This can be done by modifying the old smartphone, fixing several components so that it has a higher selling value. With that, consumers will be more interested in gathering information and increasing interest in buying Samsung smartphones. In this study social media marketing has a significant influence on consumer buying interest. Therefore Samsung must maintain and even

\footnotetext{
The Influence of Brand Image, Product Innovation and Social Media Marketing on Samsung

Smartphone's Buying Interest: Case Study on Narotama University Students

Prama Wildan Ardiansyah, Sengguruh Nilowardono
} 
increase their activity on social networks. This can be done by creating interesting content and providing accurate information about products and promotions that are currently running.

\section{REFERENCES}

Ghristian, I. D. (2016). Pengaruh harga diskon, kualitas produk, citra merek, dan iklan terhadap minat beli celana jeans Levi’s di Surabaya. ISSN 2088-7841. https://doi.org/10.14414/jbb.v5i2.552

Kotler, P., \& Keller, K. L. (2016). Marketing Management (15th ed.). Pearson Education,Inc.

Mao, Y., Zhu, J. X., \& Sang, Y. (2014). Consumer Purchase Intention Research Based on Social Media Marketing. International Journal of Business and Social Science.

Mehmood, W., \& Shafiq, O. (2015). Impact of Customer Satisfaction, Service Quality, Brand Image on Purchase Intention. Journal of Marketing and Consumer Research Journal.

Ningrum, I. T. J., \& Nilowardono, S. (2016). Pengaruh Event Dan Brand Image Terhadap Minat Beli Produk Rokok Sampoerna a Mild Pada PT HM Sampoerna Area Marketing Surabaya. Jurnal Manajemen Kinerja.

Suryani, T. (2013). Perilaku konsumen di era internet: Implikasinya pada strategi pemasaran. Yogyakarta: Graha Ilmu.

Toor, A., Husnain, M., \& Hussain, T. (2017). The impact of social network marketing on consumer purchase intention in Pakistan: Consumer engagement as a mediator. Asian Journal of Business and Accounting. 